2. Гураль Р. І. Прісноводні молюски басейну Західного Бугу в малакологічних колекціях Львова / P. І. Гураль // Наукові записки Державного природознавчого музею. - Львів, 2010. - Вип. 26. - С. 15-24.

3. Гураль-Сверлова Н. В. 50 найпомітніших молюсків Львова та околиць / Ніна Гураль-Сверлова, Роман Гураль ; відп. ред. д-р біол. наук О. С. Климишин // Національна академія наук України, Державний природознавчий музей. - Львів, 2013. - 67 с.

4. Гураль-Сверлова Н. В. Прісноводні молюски родів Planorbarius і Planorbis (Gastropoda, Pulmonata, Planorbidae) у малакологічному фонді Державного природознавчого музею / Н. В. Гураль-Сверлова, Р. І. Гураль // Наукові записки Державного природознавчого музею. - Львів, 2009. - Вип. 25. - С. 13-24.

5. Іванців В. В. Історія дослідження фауни прісноводних молюсків Волині в ХІХ ст. / В. В. Іванців // Науковий вісник ВДУ ім. Лесі Українки. - Біологічні науки. - Луцьк, 2002. - № 6. - С. 117-119.

6. Круглов Н. Д. Моллюски семейства прудовиков Европы и Северной Азии / Н. Д. Круглов. - Смоленск : СГПУ, 2005. - 508 с.

7. Стадниченко А. П. Пресноводные брюхоногие моллюски (Gastropoda) западных областей Украины : автореф. дис. ... канд. биол. наук / А. П. Стадниченко. - Львов, 1967. - 18 с.

8. Стадниченко А. П. Прудовиковые и чашечковые (Lymnaeidae, Acroloxidae) Украины / А. П. Стадниченко. - Киев : Центр учеб. лит., 2004. - 327 с.

Горанская Людмила, Теплюк Вадим. Биоэкологический анализ водных брюхоногих моллюсков истоков реки Луга. В работе рассмотрено биотопическое распределение водных брюхоногих моллюсков истоков реки Луга. Установлено, что малакофауна насчитывает 13 видов из двух подклассов и пяти семейств: Prosobranchia - 2 (Bithyniidae - 1, Viviparidae - 1), Pulmonata - 11 (Lymnaeidae - 5, Planorbidae - 5, Acroloxidae 1) видов. Наибольшую численность имеют представители семейств Planorbidae $(47,1$ \%) и Lymnaeidae $(36,6 \%)$. Массовыми являются Lymnaea stagnalis (33,7 \%) и Planorbis planorbis (21,5\%). Моллюски преимущественно заселяют тихие мелководные участки $(0,2-0,5$ м) стоячих или слабопроточных $(0,1-0,4$ м/с) частей водоемов, которые обычно заросли высшей водной растительностью. Видовой состав брюхоногих моллюсков верхнего течения реки насчитывает восемь, прудов - восемь, мелиоративных каналов - шесть видов.

Ключевые слова: брюхоногие моллюски, видовой состав, семейство, численность, распространение, река, пруды, мелиоративные каналы.

Goranska Lyudmila, Tepliuk Vadym. Bio-ecological Analysis of Water Gastropods of Origins Luga River. The paper reviewed the biotopical distribution of aquatic gastropods of origins Luga River. It has been established that fauna of mollusks has 13 species from 2 subclasses and 5 families: Prosobranchia - 2 (Bithyniidae -1 , Viviparidae - 1), Pulmonata - 11 (Lymnaeidae - 5, Planorbidae - 5, Acroloxidae - 1) species. There is the greatest abundance of representatives of families Planorbidae $(47,1 \%)$ and Lymnaeidae $(36,6 \%)$. Lymnaea stagnalis $(33,7 \%)$ and Planorbis planorbis $(21,5 \%)$ are the mass species. Mostly mollusks inhabit in quiet shallow areas $(0,2-0,5 \mathrm{~m})$ of standing or slightly flowing $(0,1-0,4 \mathrm{~m} / \mathrm{s})$ parts of reservoirs, which usually are overgrown with aquatic vegetation. Species composition of gastropods of the upper course of the river has 8 species, ponds -8 species, meliorative channel 6 species.

Key words: gastropods, species composition, the family, the abundance, the distribution, the river, ponds, meliorative channel.

Стаття надійшла до редколегії 26.02.2016 p.

УДК 595. 14:591.553(477)

Леся Бусленко, Петро Сидорчук

\title{
Структура популяцій люмбрицид (Oligochaeta, Lumbricidae) у біогеоценозах горбогір'я Вороняків
}

Видовий склад дощових черв'яків у біоценозах горбогір'я Вороньків представлений дванадцятьма видами з восьми родів родини Lumbricidae. Найбільше видове багатство відзаначено для біоценозів заплавних лук, 
найменший індекс видового багатства в агроценозах. Досліджені комплекси люмбрицид формують два кластери, на утворення яких впливає режим зволоження.

Ключові слова: дощові черв'яки, люмбрициди, біоценози, видове багатство, подібність фаун.

Постановка наукової проблеми та її значення. Грунтоутворювальна роль дощових черв'яків це один із найважливіших біотичних факторів, що має широкий спектр дії на біологічну активність грунту. Популяційні дослідження люмбрикофауни є невід’ємною складовою частиною моніторингу грунтів як у заповідних територіях, так і в районах інтенсивного впливу на природні комплекси, оскільки в більшості екосистем домінуюча за біомасою група в багатьох випадках визначає біогенну міграцію хімічних елементів і продуктивність екосистем $[3,12]$. Установлення структури популяцій один із важливих компонентів оцінки екології окремих груп тваринних організмів, зокрема й дощових черв'яків, які в помірному поясі є домінуючою сапротрофною групою у всіх біоценозах. Зміни чисельності, біомаси, видового складу люмбрицид свідчать про істотні перебудови в наземних екосистемах [1].

Мета дослідження - проаналізувати структуру популяцій люмбрицид у зв'язку зі зміною біоценотичних факторів (індекс видового багатства, або індекс Маргалефа, для кількісного порівняння фаун - коефіцієнт Брея-Кертіса, для якісного порівняння - індекс Чекановського-Серенсена).

Район дослідження. Вороняки належать до зони лісостепу, розміщеної в північній частині Західно-Подільської області. Для Вороняків характерні структурно-денудаційні сильно розчленовані горбогір'я із сірими й темно-сірими лісовими грунтами, дубово-буковими лісами. Вороняки простягаються від Гологор на заході до Кременецького кряжу на сході. Абсолютні висоти сягають 350-400 м. Характерні зрілі ерозійно-денудаційні форми, наявність таких останців, як Почаївська гора, Підкамінь, Білий камінь. Ці місцевості утворюють верхній ландшафтний рівень у лісостепових фізико-географічних областях. Унаслідок висотного положення, розчленування й значного зволоження атмосферними опадами на всій території розвинуті сірі лісові грунти. На підвищених елементах рельєфу зростають дубово-букові ліси. Для горбогірних місцевостей характерні урочища вододільних останців, зайнятих сільськогосподарськими угіддями, балки і яри з чагарниковою рослинністю та конуси виносу, на яких сформувались опідзолені чорноземи [11].

Матеріал та методи дослідження. Матеріалом для роботи слугували кількісні збори малощетинкових черв'яків родини Lumbricidae в природних й антропогенних ценозах Вороняків. Збір та облік люмбрицид проводили двічі на рік, навесні й восени, упродовж 2014-2015 pp. за загальновизнаною методикою грунтових розкопок [4]. Ідентифікацію дощових черв'яків здійснювали за визначником Т. С. Перель [8]. Для оцінки видового різноманіття люмбрицид у різних біоценозах використовували індекс видового багатства (індекс Маргалефа).

Кількісне порівняння фаун у біоценозах проводили за коефіцієнтом Брея-Кертіса. Якісне порівняння фаун здійснювали за індексом Чекановського-Серенсена $[6,7,9]$.

Виклад основного матеріалу й обгрунтування отриманих результатів дослідження. У ході досліджень виділено декілька типів біоценозів за характером рослинності:

I - свіжі складні субори. Такі типи лісів у лісостеповій зоні займають підвищені, рівні, добре дреновані місцевості. Корінні насадження багатоярусні, перший ярус представлений сосною, другий дубом, до якого примішуються береза, осика, клен гостролистий, липа, граб. Більшість дерев трьох останніх порід відстає в рості від дуба та утворює третій ярус. У підліску ліщина, бруслина бородавчаста і європейська, свидина, татарський клен та бузина. Трав'яний покрив представлений, суборовими й дібровними видами: орляк (Pteridium aquilinum Kuhn), медунка вузьколиста (Pulmonaria angustifolia L.), буквиця лікарська (Betonica oficinalis L.), герань криваво-червона (Geranium sanguineum L.), копитняк європейський (Asarum europeum L.), медунка широколиста (Pulmonaria officinalis L.), чоловіча папороть (Driopterix filix mas Schott).

II - вільхові ліси, що найчатіше трапляються на підніжжях схилів, де рівень грунтових вод виходить на поверхню з-під плакора. У деревостої переважає чорна вільха 3 домішками берези пухнастої, у підліску - верба болотна, вільха сіра, іноді - черемха й чорна смородина. У покриві ірис жовтий (Iris pseudoacorus L.), осока пухирчаста (Carex vesicaria L.), папороть жіноча (Athyrium 
filix femina Roth), болотна папороть (Driopterix thelipteris Gray), калюжниця (Calta palustris L.), ситник (Juncus effusus L.), мох (Acrocladium cuspidatum Lingb).

III - свіжі діброви, які є найбільш поширеним типом дібров у районі дослідження. Ними зайняті рівні плато або пологі схили різних експозицій. Корінні насадження свіжих дібров мають складну форму: у першому ярусі - дуб, ясен, у другому - клен гостролистий, липа, клен польовий, груша, яблуня. Підлісок відсутній через недостатнє освітлення. Характерними й переважаючими в трав'яному покриві є яглиця звичайна (Aegopodium podagraria L.), ясмінник пахучий (Asperula odorata L.), медунка широколиста (Pulmonaria officinalis L.), копитняк (Asarum europeum L.), зеленчук (Lamium galeobdolon L.), чоловіча папороть (Driopterix filix mas Schott), осока волосиста (Carex pilosa Scop), підлісник європейський (Sanicula europaea L.), вівсяниця гігантська (Festuca gigantea Vill).

IV - свіжі бучини. Займають пологі схили, іноді - рівні місця або пониження з добрим дренажем і стоком поверхневих вод. У насадженнях корінної форми домінує бук із додаванням дуба, ясена, явора, клена гостролистого. Другий ярус складений грабом, розвиток якого залежить від густоти деревостою бука. Підлісок відсутній, трав'яний покрив розвинений слабо. Типовими $є$ такі види, як ясмінник пахучий (Asperula odorata L.), медунка широколиста (Pulmonaria officinalis L.), чоловіча папороть (Driopterix filix mas Schott), снить (Aegopodium podagraria L.), зеленчук (Lamium galeobdolon Grantz), шавлія клейка (Salvia glutinosa L.).

$\mathrm{V}$ - заплавні луки, що на території Вороняків добре сформувались у долинах річок. Вони утворилися внаслідок неглибокого врізання русла в річкову долину, легкого гранулометричного складу грунтів, тектонічного опускання місцевості в минулому. Рослинний покрив у флористичному відношенні небагатий. Серед рослин домінують Poa pratensis L, Agrostis capillaris L., Anthoxanthum odoratum L., Festuca pratensis Huds.

VI - вербняк - це тип лісу, поширення якого обмежується виключно берегами річок. У флористичному відношенні для цих біоценозів характерне поширення різних видів верби: Salix alba L., $S$. amygdalina $L ., S$. viminalis $L$. Основний фон трав'яного покриву утворюють Scutellaria galericulata $L$., Sonchus arvensis L., Canvolvutus sepium R. Br., Galium rubioides L., Lucopus exaltatus L. [10]

VII - перелоги. На площах покинутих полів формується неоднорідний надгрунтовий покрив. Відбувається поступове формування рослинних асоціацій, які властиві суходільним лукам - Adonis vernalis L., Trifolium arvense L., Trifolium campestre Schreb, Trifolium pratense L., Poa angustifolia L., Poa annua L., Bromus inermis Leyss, Bromus arvensis L., Hypericum perforatum L.

VIII - агроценози. Майже всі ділянки розорані й зайняті різноманітними сільськогосподарськими культурами (пшениця, кукурудза, ріпак, ячмінь, овес, гречка, цукрові буряки, картопля, овочеві культури та ін.).

Повний перелік видів олігохет із родини Lumbricidae для цієї території подається вперше. У літературі наявні фрагментарні дані щодо видового складу та екологічних характеристик люмбрицид Вороняків [5]. У результаті проведених зборів нами ідентифіковано 12 видів дощових черв'яків: Allolobophora chlorotica (Savigni, 1826); Aporrectodea caliginosa (Savigni,1826), Aporrectodea trapezoides (Duges, 1928), Aporrectodea rosea (Savigni, 1826); Dendrobaena octaedra (Savigni, 1826); Dendrodrilus tenuis (Eisen, 1874); Lumbricus terrestris (Linnaeus, 1758), Lumbricus castaneus (Savigny, 1826), Lumbricus rubellus (Hoffmeister, 1843); Octolasion lacteum (Oerley, 1855); Eisenia fetida (Savigni, 1826); Eiseniella tetraedra intermedia (Černosvitov, 1934).

Важливою мірою оцінки різноманіття, для обмеженого в просторі екологічного угрупування $\epsilon$ видове багатство. Воно найбільше для біоценозів заплавних лук, оскільки умови достатнього зволоження за рахунок близького залягання грунтових вод та розвиток трав'яної рослинності сприяють розвитку дощових черв'яків трьох морфоекологічних груп. Найменший індекс видового багатства в агроценозах, оскільки, відсутність постійного рослинного покриву та механічний обробіток грунту елімінують підстилкову та грунтово-підстилкову морфоекологічну групу, тим самим зменшують кількість зареєстрованих видів у цьому біоценозі (рис. 1).

У фауністичних дослідженнях часто порівнюють склад фауни різних біоценозів. Подібність фаун Lumbricidae оцінюють за допомогою індексу Чекановського-Серенсена (для якісних показників) та коефіцієнта Брея-Кертіса (для кількісних показників). 


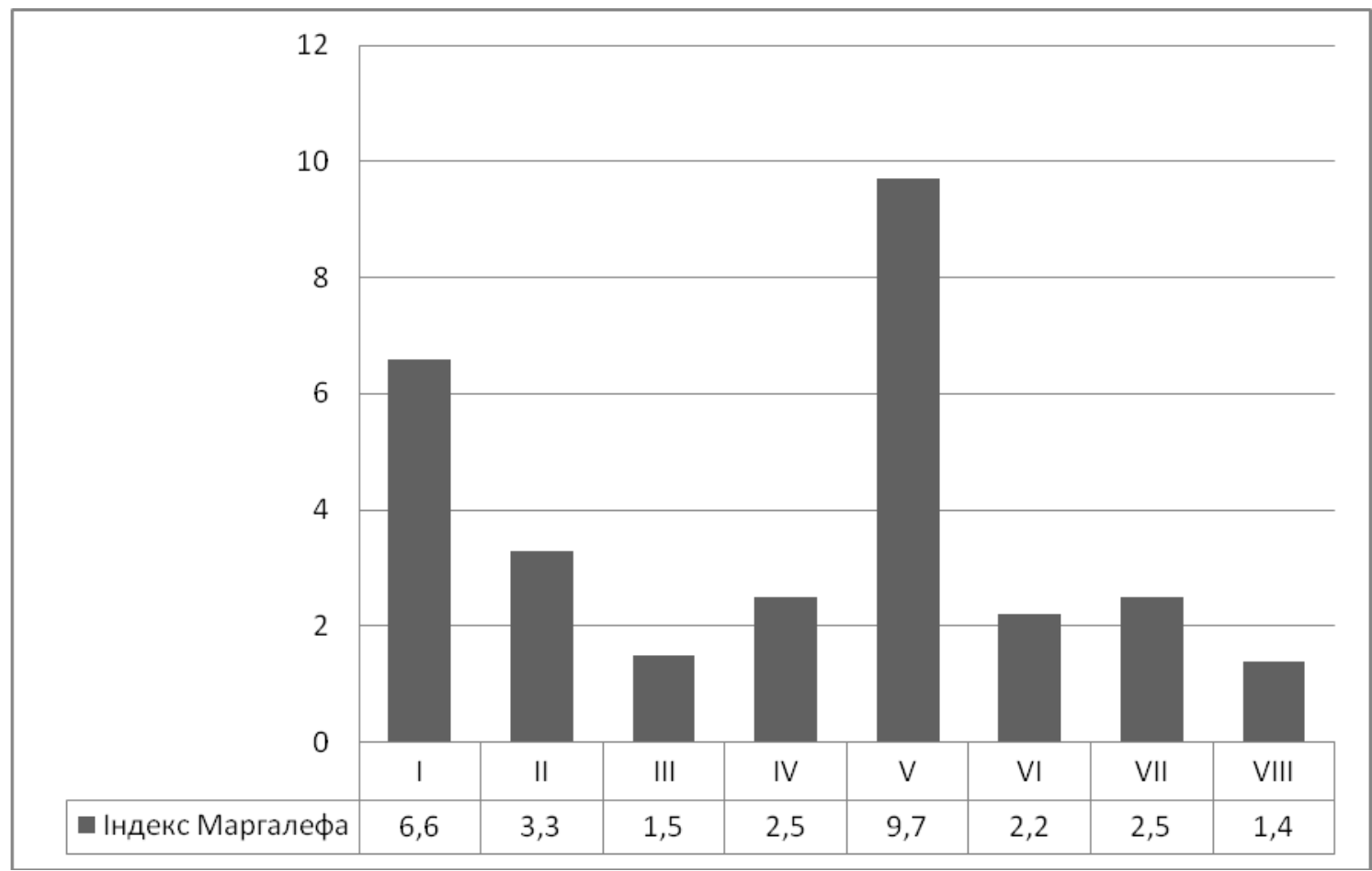

Рис. 1. Показники індексу видового багатства (індекс Маргалефа) у біоценозах Вороняків

Установлено, що найбільшу біоценотичну подібність мають комплекси люмбрицид вільхових лісів і заплавних лук, а найменшу подібність угрупування люмбрицид біоценозів заплавних лук та агроценозів (за кількісними показниками). За якісними показниками найбільшу біоценотичну подібність мають угрупування дощових черв'яків перелогів й агроценозів; верболозів і перелогів, свіжих дібров, свіжих складних суборів; перелогів та свіжих складних суборів (табл. 1).

Таблиия 1

Показники попарної біоценотичної подібності люмбрицид

\begin{tabular}{|l|l|l|l|l|l|l|l|l|}
\hline Біоценоз & \multicolumn{1}{|c|}{ I } & \multicolumn{1}{|c|}{ II } & \multicolumn{1}{|c|}{ III } & \multicolumn{1}{c|}{ IV } & \multicolumn{1}{c|}{ V } & \multicolumn{1}{c|}{ VI } & \multicolumn{1}{c|}{ VII } & VIII \\
\hline I & 1 & 0,45 & 0,45 & 0,30 & 0,43 & 0,48 & 0,48 & 0,45 \\
\hline II & $\mathbf{0 , 4 0}$ & 1 & 0,40 & 0,43 & 0,43 & 0,43 & 0,45 & 0,40 \\
\hline III & $\mathbf{0 , 4 2}$ & $\mathbf{0 , 3 3}$ & 1 & 0,43 & 0,42 & 0,48 & 0,45 & 0,44 \\
\hline IV & $\mathbf{0 , 4 0}$ & $\mathbf{0 , 3 8}$ & $\mathbf{0 , 3 8}$ & 1 & 0,45 & 0,46 & 0,44 & 0,40 \\
\hline V & $\mathbf{0 , 3 8}$ & $\mathbf{0 , 4 7}$ & $\mathbf{0 , 3 6}$ & $\mathbf{0 , 4 1}$ & 1 & 0,44 & 0,43 & 0,36 \\
\hline VI & $\mathbf{0 , 4 6}$ & $\mathbf{0 , 3 8}$ & $\mathbf{0 , 4 5}$ & $\mathbf{0 , 4 3}$ & $\mathbf{0 , 4 0}$ & 1 & 0,48 & 0,38 \\
\hline VII & $\mathbf{0 , 4 3}$ & $\mathbf{0 , 4 1}$ & $\mathbf{0 , 4 2}$ & $\mathbf{0 , 4 0}$ & $\mathbf{0 , 3 8}$ & $\mathbf{0 , 4 6}$ & 1 & 0,48 \\
\hline VIII & $\mathbf{0 , 4 2}$ & $\mathbf{0 , 3 3}$ & $\mathbf{0 , 4 0}$ & $\mathbf{0 , 3 1}$ & $\mathbf{0 , 2 9}$ & $\mathbf{0 , 3 6}$ & $\mathbf{0 , 4 2}$ & 1 \\
\hline
\end{tabular}

Примітка. Аналіз якісних показників - зверху, справа, курсивом; аналіз кількісних показників - знизу, зліва.

У результаті проведеного кластерного аналізу популяційні угруповання люмбрицид у восьми біоценозах поділено (на рівні 60 \%) на дві групи 3 дуже низьким рівнем зв'язку між собою. При такому розподілі визначальним фактором $\epsilon$ режим зволоження грунту. У першому кластері представлено біоценози (свіжі складні субори, свіжі діброви, перелоги, агроценози), у яких грунтова волога дуже швидко втрачається через тип грунту або характер рослинного покриву. До другого кластера увійшли біоценози (вільхові ліси, свіжі бучини, заплавні луки, вербняки) грунт яких має достатнє насичення вологою. Це забезпечується або близьким заляганням грунтових вод, або фітоценотичними умовами, які сприяють збереженню грунтової вологи (рис. 2). 


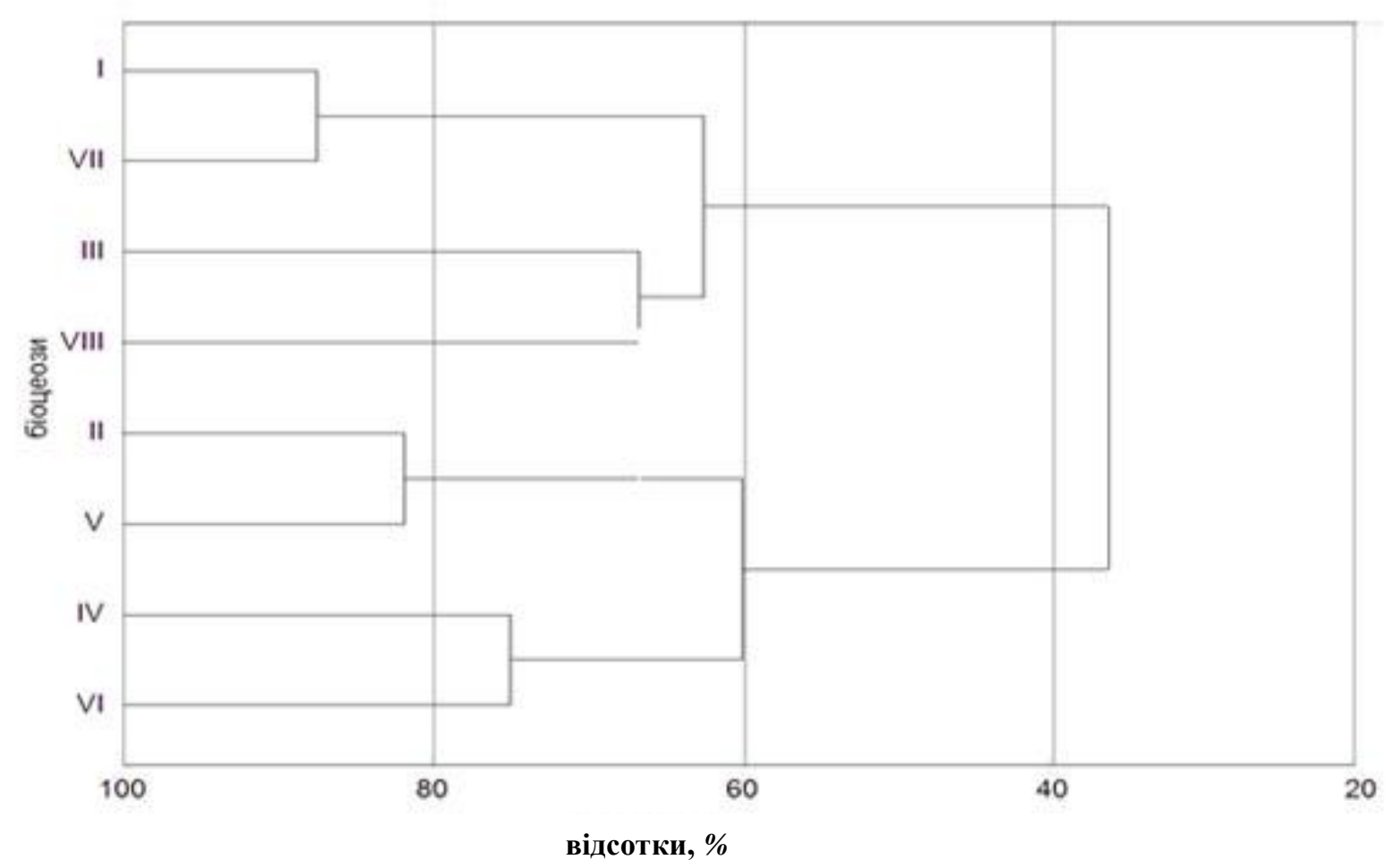

Рис. 2. Дендрограма біоченотичної подібності видових комплексів люмбрицид (метод повних зв 'язків; матриия подібностей за коефічієнтом Жаккарда), I - свіжі складні субори, II - вільхові ліси, III - свіжі діброви, IV - свіжі бучини, V-заплавні луки, VI-вербняки, VII - перелоги, VIII - агроченози.

Висновки й перспективи подалыших досліджень. Незважаючи на невелику територію горбогір'я Вороняків, йому властиве велике різноманіття грунтового покриву. Причинами диференціації грунтового покриву й розвитку грунтових комбінацій слугують просторова різноманітність виявів чинників грунтоутворення та історія формування біоценозів. Завдяки популяційним дослідженням комплексів люмбрицид Вороняків, у природних й антропогенно змінених біоценозах виявлено 12 видів дощових черв'яків. Видова структура популяцій досліджуваної групи організмів зазнає істотних змін під впливом біоценотичних факторів, зокрема характеру рослинності.

Видове багатство як важливий критерій оцінки різноманіття характеризує ступінь розвитку комплексів люмбриццид у біоценозі. Для окремих біоценозів характерна подібність комплексів дощових черв'яків, що визначається однаковими екологічними потребами видів, які в них розвиваються, та одноманітністю біоценотичних параметрів. Установлено високий рівень спільності популяцій люмбрицид для вільхових лісів і заплавних лук, перелогів й агроценозів. Найбільш своєрідною є фауна дощових черв'яків в агроценозах. Завдяки кластерному аналізу встановлено популяційну подібність комплексів люмбрицид залежно від фітоценотичних умов.

\section{Джерела та література}

1. Артемьева Т. И. Комплексы почвенных животных и вопросы рекультивации техногенных территорий / Т. И. Артемьева. - М. : Наука, 1989. - 111 с.

2. Гаськевич О. В. Сруктура грунтового покриву Гологоро-Кременецького горбогір'я / О. В. Гаськевич, С. П Позняк. - Львів : Вид. центр ЛНУ ім. Івана Франка, 2007. - 208 с.

3. Гиляров М. С. Зоологический метод диагностики почв / М. С. Гиляров. - М. : Наука, 1965. - 279 с.

4. Гиляров М. С. Учет крупных почвенных беспозвоночных (мезофауна) / М. С. Гиляров // Методы почвенно-зоологических исследований. - М. : Наука, 1975. - С. 12-29.

5. Іванців В. В. Структурно-функціональна організація комплексів грунтових олігохет західного регіону України / В. В. Іванців. - Луцьк : РВВ «Вежа» ВДУ ім. ЛесіУкраїнки, 2007. - 400 с.

6. Лебедева Н. В. Биологическое разнообразие : учеб. пособие для студ. висш. учеб. заведений / Н. В. Лебедева, Н. Н. Дроздов, Д. А. Криволуцький. - М. : Гуманит. изд. центр ВЛАДОС, 2004. - 432 с.

7. Мэгарран Э. Экологическое разнообразие и его измерение / Э. Мэгарран. - М. : Мир, 1992. - 181 с. 
8. Перель Т. С. Распространение и закономерности распределения дождевых червей фауны СССР / Т. С. Перель. - М. : Наука, 1979. - 272 с.

9. Песенко Ю. А. Принципы и методы количественного анализа в фаунистических исследованиях / Ю. А. Песенко. - М. : Наука, 1982. - 289 с.

10. Погребняк П. С. Основы лесной типологии / П. С. Погребняк. - К. : Изд-во академии наук Украинской CCP, 1959. - $456 \mathrm{c}$.

11. Природа Украинской ССР. Ландшафты и физико-географическое районирование / А. М. Маринич, В. М. Пащенко, П. Г. Шищенко [и др.]. - Киев : Наук. думка, 1985. - 224 с.

12. Lee K. E. Earthworms: their ecology and relationships with soil and Land use / K. E. Lee. - London : Acad. Press, 1985. $-411 \mathrm{p}$.

Бусленко Леся, Сидорчук Петр. Структура популяций люмбрицид (Oligochaeta, Lumbricidae) в биогеоценозах Вороняков. Видовой состав дождевых червей в биоценозах Вороняков представлен двенадцатью видами из восьми родов семейства Lumbricidae. Популяционная структура коммплексов дождевых червей Вороняков позволяет охарактеризовать основные свойства почв. Видовой состав комплексов люмбрицид может варьировать в значительных пределах конкретного типа биоценоза. Важное значение в формировании комплекса люмбрицид в биоценозах обусловлено режимом влажности. Ведь она выступает регулятором жизнедеятельности дождевых червей. Видовое разнообразие исследуемой группы - это важная оценка в популяционних экологических измерениях. Кластерным анализом установлено популяционное сходство комплексов люмбрицид в зависимости от режима влажности почв.

Ключевые слова: дождевие черви, люмбрициды, биоценозы, видовое богатство, сходство фаун.

Buslenko Lesia, Sydorchuk Petro. The Structure of the Population Lumbricid (Oligochaeta, Lumbricidae) in Ecosystems Voronyak. The species composition of earthworms in biocenoses Voronyak presented twelve species of eight genera of the family Lumbricidae. Population structure earthworms Voronyakov be characterized allows the basic properties of the soil. Species composition lumbricid complexes can vary quite a particular type of ecological community. Important in the formation of the complex lumbricid in ecosystems caused by moisture regime. Bring it appears vital activity of earthworms regulator. Species diversity is an important study groupies assessment in population ecological dimensions. Cluster analysis revealed similarities population lumbricid complexes, depending on the soil moisture regime.

Key words: earthworms, lumbricid, biocenoses, population, species riches, similarity faunas biodiversity, Voronyaki.

Стаття надійшла до редколегії 21.03.2016 p.

УДК 504.45:597.2/.5

\section{Ольга Бєдункова}

\section{Генотоксичний моніторинг річки Стир у межах Рівненської області}

Представлено результати проведення генотоксичного моніторингу р. Стир у межах Рівненської області за допомогою мікроядерного тесту периферійної крові риб. 3'ясовано, що найвищі рівні ядерних порушень характерні для плітки та окуня річкового, а найменші - для карася сріблястого. Ядерні порушення ляща, верховодки й краснопірки займали проміжне положення. Рівні ядерних порушень старших вікових груп риб були вищими, порівняно з однорічками, у середньому на 9,6 \%. Перевищення рівнів спонтанних мутацій еритроцитів крові риб зафіксовані лише для плітки $(5,62 \pm 0,59 \%$ ) та окуня річкового $(4,73 \pm 0,78 \%$ \%) нижче скиду з очисних споруд смт Зарічне, що свідчить про наявність мутагенних факторів у складі стічних вод. Загальний генотоксичний потенціал досліджуваної частини річки є незначним, що також може бути обумовлено високою адаптивною стійкістю досліджуваних видів риб.

Ключові слова: генотоксичність, ядерні порушення, цитогенетичний гомеостаз.

Постановка наукової проблеми та їі значення. Окремі забруднювачі водного середовища можуть бути небезпечні в надзвичайно низьких концентраціях, проявляти синергізм та адитивність, виступати в якості мутагенів або промутагенів і при цьому не фіксуються за звичайного хімічного аналізу води $[1,2]$. Тому важливою складовою частиною гідроекологічних досліджень $є$ моніторинг генотоксичного забруднення водойм [3].

(C) Бєдункова О., 2016 